\title{
Neurologists strike gold in drug screen effort
}

Alison Abbott

A number of drug leads and the prospect of a deeper understanding of neurodegenerative diseases have emerged from the first 'community screen' in the United States.

The programme, run by the National Institute of Neurological Disorders and Stroke (NINDS) in Bethesda, Maryland, brought together a wide community of scientists in a search for interesting compounds. Between them, they tested about 1,000 drugs, most of which are already in use as treatments for conditions unrelated to neurological illness.

The drugs, whose identities were kept secret from the researchers, were screened over a six-month period in 29 different laboratory tests that model neurodegenerative disorders such as Alzheimer's disease and amyotrophic lateral sclerosis (ALS).

The investigators involved met in Washington last month to discuss the results. "It was very exciting," says Jeffrey Rothstein, a neuroscientist at Johns Hopkins Medical School in Baltimore. "We had all cranked awayblind for six months, and then welearnt that there had been hits in different assays with classes of drug used clinically for indications which have nothing to do with the nervous system."

Allan Tobin, director of the Brain Research Institute at the University of California, Los Angeles, also participated in the experiments. "This is the most exciting enterprise I have been involved in since we discov- ered the Huntington's gene," he says, referring to the 1993 gene find that he organized.

The screening effort is part of wider push by the National Institutes of Health to improve the translation of basic research results into clinical use. The tests were done by investigators who already have grants either from NINDS or from three voluntary organizations that co-sponsored the programme - the ALS Association, the Huntington's Disease Society and the Hereditary Disease Foundation.

Three-quarters of the drugs tested are already approved by the US Food and Drug Administration (FDA), and the rest were selected because they influence brain activity. These included controlled substances, such as cannabinoids, the active ingredients in marijuana.

Investigators are most excited about what the screens, in which so many different parameters were altered by exposure to so many different classes of drug, will reveal about the biology of neurodegenerative diseases, rather than the prospect of immediate clinical benefits. Some say that this is analogous to the sort of information that emerges from DNA microarray studies that measure expression of hundreds of thousands of genes, or from large-scale genetic screens.

But many leads have already emerged, according to Jill Heemskerk, the project organizer at NINDS. The investigators are currently keeping quiet about which compounds have shown good activity — but

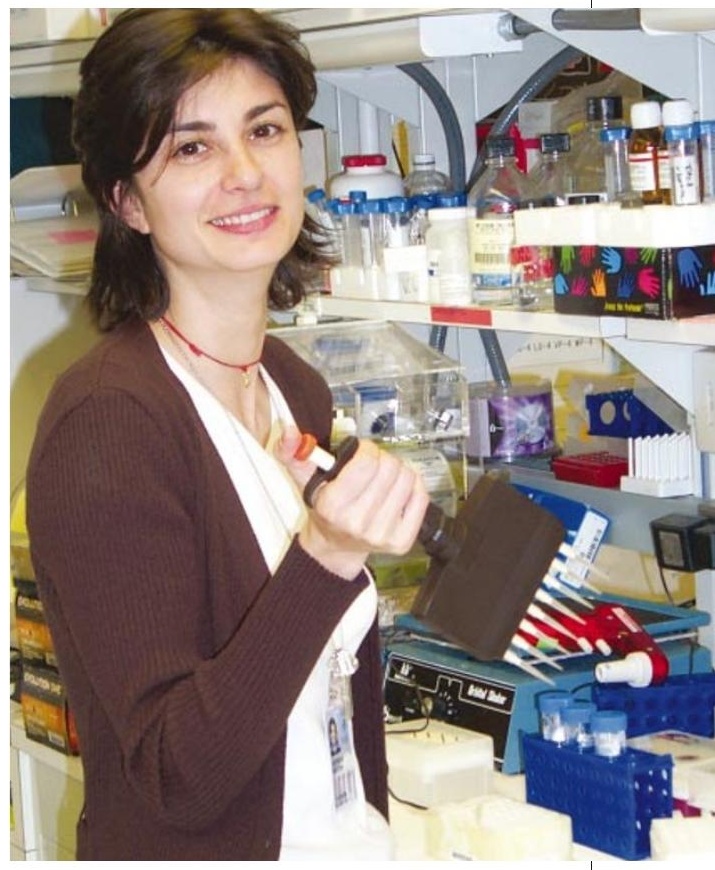

Active approach: postdoc Federica Piccioni joins in the NIH's search for neurological agents.

some are already being prepared for followup studies in mice, says Heemskerk.

NINDS hopes that some of the hits will eventually move into clinical trials. If so, the trials could be completed rapidly as many of the compounds already have FDA approval, says Heemskerk. The concept might also be extended to other diseases, she adds.

\section{Badgers set for cull in resumed tuberculosis trial}

\section{David Adam, London}

Trials in which thousands of badgers will ultimately be killed to investigate their role in spreading bovine tuberculosis (TB) have

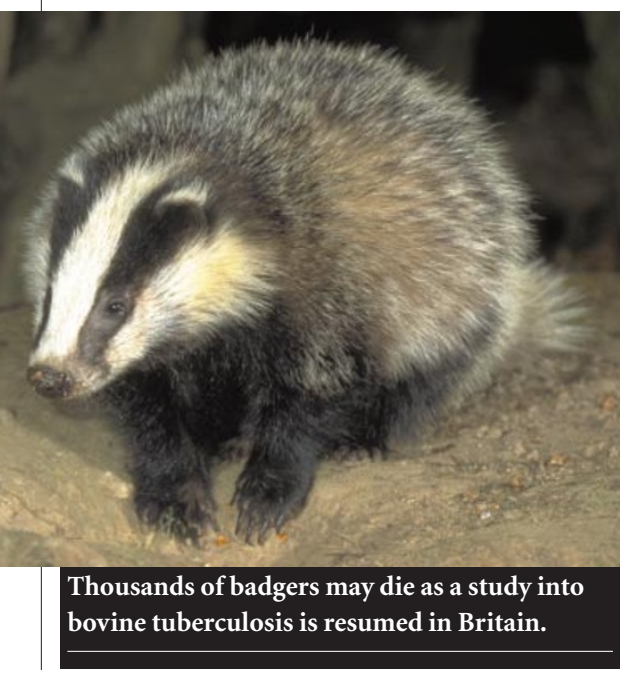

resumed in Britain amid fresh arguments over the study's aims and effectiveness.

The trials - suspended early last year because of the country's outbreak of footand-mouth disease - are intended to show whether strategic culls of badgers could combat the spread of TB in cattle, which is a growing problem in parts of Britain.

"It is a tragedy that these trials are resuming when a growing body of scientific evidence indicates that cattle-to-cattle transmission is the major cause of the increase in bovine TB," says Elaine King, a zoologist and chief executive of the National Federation of Badger Groups.

Other scientists say that the situation is not so straightforward. "Badgers are part of the problem and continuing these trials is the only way to quantify how big a part they play," says Tim Roper, an animal-behaviour researcher at Sussex University.

The trials are designed to compare three strategies: killing all badgers in an area; removing them only if a case of bovine $\mathrm{TB}$ is spotted; and no culling at all. But they have been dogged by delays and controversy since they were first proposed in 1997 (see Nature $394,821 ; 1998)$. In a 1999 report, the House of Commons Select Committee on agriculture questioned whether the trials will produce statistically meaningful results.

Stephen Harris, a zoologist at Bristol University who runs the UK National Badger Survey and is a long-standing critic of the trials, describes them now as a "farce". Large numbers of cattle will have been replaced in trial areas since the outbreak of foot-andmouth, he says, making it impossible to relate test results to the culling of badgers.

John Bourne, head of the government's Independent Scientific Group on bovine TB, which is running the trials, dismisses Harris's criticisms, saying that only about $5 \%$ of farms in trial areas were affected by foot-and-mouth, and that trial results due in 2005 - will still be valid. 